Meta

Journal des traducteurs

Translators' Journal

\title{
Cohesive Devices in Translator Training: A Study Based on a Romanian Translational Learner Corpus
}

\section{Mona Arhire}

Volume 62, numéro 1, avril 2017

URI : https://id.erudit.org/iderudit/1040471ar

DOI : https://doi.org/10.7202/1040471ar

Aller au sommaire du numéro

Éditeur(s)

Les Presses de l’Université de Montréal

ISSN

0026-0452 (imprimé)

1492-1421 (numérique)

Découvrir la revue

Citer cet article

Arhire, M. (2017). Cohesive Devices in Translator Training: A Study Based on a Romanian Translational Learner Corpus. Meta, 62(1), 155-177.

https://doi.org/10.7202/1040471ar
Résumé de l'article

Les liens formels sont naturellement associés à la cohésion, qui est l'une des principales caractéristiques du discours. La cohésion a été largement discutée dans la littérature, en particulier en termes de mécanismes générateurs, mais aussi en termes d'équivalence dans la traduction. Comme dans le cas de tout type de discours, la valeur communicative des textes traduits est renforcée par leur texture cohésive. Toutefois, on a accordé moins d'attention à la traduction de liens formels comprenant des fonctions supplémentaires. Cette étude examine certains dispositifs de la cohésion dans les traductions des étudiants avec une attention particulière à la traductibilité de l'ellipse, la substitution et la référence, lorsqu'elles sont enrichies par des valeurs stylistiques, rhétoriques et sociolectales. L'étude est basée sur un corpus d'apprentissage de la traduction constitué des traductions d'un court récit de l'anglais vers le roumain, effectuées par des étudiants roumains diplômés. La méthodologie pour évaluer et analyser le corpus d'apprentissage est à la fois quantitative et qualitative, et emploie la simplification, l'explicitation et la neutralisation. Les conclusions comprennent des aperçus sur certaines zones problématiques dans les traductions des stagiaires, ainsi que des observations relatives aux aspects contrastifs de dispositifs de la cohésion entre l'anglais et le roumain. Une méthodologie d'enseignement est ensuite tirée des conclusions dans une tentative d'offrir une approche plus compréhensible de la pédagogie de la traduction de la cohésion avec une charge stylistique.
Ce document est protégé par la loi sur le droit d'auteur. L'utilisation des services d'Érudit (y compris la reproduction) est assujettie à sa politique d'utilisation que vous pouvez consulter en ligne.

https://apropos.erudit.org/fr/usagers/politique-dutilisation/ 


\title{
Cohesive Devices in Translator Training: A Study Based on a Romanian Translational Learner Corpus
}

\author{
MONA ARHIRE \\ Transilvania University, Brașov, Romania \\ mona.arhire@unitbv.ro
}

\section{RÉSUMÉ}

Les liens formels sont naturellement associés à la cohésion, qui est l'une des principales caractéristiques du discours. La cohésion a été largement discutée dans la littérature, en particulier en termes de mécanismes générateurs, mais aussi en termes d'équivalence dans la traduction. Comme dans le cas de tout type de discours, la valeur communicative des textes traduits est renforcée par leur texture cohésive. Toutefois, on a accordé moins d'attention à la traduction de liens formels comprenant des fonctions supplémentaires. Cette étude examine certains dispositifs de la cohésion dans les traductions des étudiants avec une attention particulière à la traductibilité de l'ellipse, la substitution et la référence, lorsqu'elles sont enrichies par des valeurs stylistiques, rhétoriques et sociolectales. L'étude est basée sur un corpus d'apprentissage de la traduction constitué des traductions d'un court récit de l'anglais vers le roumain, effectuées par des étudiants roumains diplômés. La méthodologie pour évaluer et analyser le corpus d'apprentissage est à la fois quantitative et qualitative, et emploie la simplification, l'explicitation et la neutralisation. Les conclusions comprennent des aperçus sur certaines zones problématiques dans les traductions des stagiaires, ainsi que des observations relatives aux aspects contrastifs de dispositifs de la cohésion entre l'anglais et le roumain. Une méthodologie d'enseignement est ensuite tirée des conclusions dans une tentative d'offrir une approche plus compréhensible de la pédagogie de la traduction de la cohésion avec une charge stylistique.

\begin{abstract}
Formal links are naturally associated with cohesion as one of the main features of discourse. Cohesion has been extensively discussed in the literature especially in terms of the mechanisms generating it, but also in terms of its equivalence in translation. As with any type of discourse, the communicative value of translated texts is enhanced by their cohesive texture. Less attention has been granted to the translation of formal links carrying additional functions though. This study examines some cohesive devices in student translations with a special focus on the translatability of ellipsis, substitution and reference when they are enriched with stylistic, sociolectal and rhetorical values. The study is based on a translational learner corpus consisting of Romanian graduate students' translations of a short story from English into Romanian. The methodology for assessing and analyzing the learner corpus is of both quantitative and qualitative nature and employs simplification, explicitation and neutralization. The conclusions comprise insights into some problematic areas in the trainees' translations, as well as observations related to contrastive aspects of cohesive devices between English and Romanian. A teaching methodology is subsequently derived from the findings in an attempt to offer a more comprehensive approach to the pedagogy of translating cohesive devices with stylistic load.
\end{abstract}




\section{RESUMEN}

Las conexiones formales están naturalmente asociadas a la cohesión como un rasgo principal del discurso. La cohesión ha sido largamente debatida en la literatura, especialmente en cuanto a los mecanismos que la generan, pero igualmente en cuanto a sus equivalencias en la traducción. Como ocurre con cualquier tipo de discurso, el valor comunicativo de los textos traducidos es resaltado por su carácter cohesivo. Sin embargo, se ha prestado menos atención a la traducción de conexiones formales dotadas de funciones adicionales. El presente estudio analiza algunos recursos de cohesión en las traducciones de estudiantes, con especial atención a la traducibilidad de la elipsis, la sustitución y la referencia cuando aparecen enriquecidas por valores estilísticos, sociolectales y retóricos. Este estudio se basa en un corpus de aprendices de la traducción que consta de traducciones de un cuento, del inglés al rumano, realizadas por estudiantes licenciados rumanos. La metodología para evaluar y analizar el corpus de aprendices es tanto cuantitativa como cualitativa y utiliza simplificación, explicitación y neutralización. La conclusión proporciona conocimiento sobre algunas áreas problemáticas de las traducciones de los aprendices, así como observaciones relacionadas con los aspectos contrastivos de los recursos de cohesión entre el inglés y el rumano. Una metodología didáctica se desprende a raíz de estos hallazgos, en un intento de ofrecer un enfoque más comprensivo de la pedagogía de la traducción de los recursos de cohesión con valor estilístico.

\section{MOTS-CLÉS/KEYWORDS/PALABRAS CLAVE}

dispositifs de la cohésion, fonction stylistique, contrastivité, corpus d'apprentissage de la traduction, formation des traducteurs

cohesive devices, stylistic function, contrastiveness, translational learner corpus, translator training

recursos de cohesión, función estilística, contrastividad, corpus de aprendices de la traducción, formación de traductores

\section{Introduction}

Cohesive devices can be defined in very broad terms as representing the formal means of connecting parts of texts so as to favour the creation of a meaningful continuum. The coherent flow of the written discourse as a unitary whole depends to an important extent on the effective use of cohesive devices. Discourse analysis and textual linguistics are the disciplines chiefly dealing with cohesion, but sundry other study areas take various stances in investigating formal links (namely pragmatics, syntax and semantics). Translation Studies is no exception since its object of study is the inter-linguistic transfer of the written discourse. The study presented in this paper analyzes the translation of some cohesive devices (ellipsis, substitution and reference) from English into Romanian. It is based on a learner corpus collected from homework assigned to translation trainees, students of the Faculty of Letters at Transilvania University of Braşov, Romania. The results of the analysis are primarily expected to have a bearing upon the educational environment that generated them, but they should raise interest in similar translator training settings and represent a starting point for more extensive investigations into the translational and contrastive aspects of cohesive devices. 


\section{Preliminaries and Objectives}

The idea of this study emerged from observing recurrent inappropriate inter-linguistic transfer of some cohesive devices in the graduate learners' translations. This occurred in the context in which the trainees had been previously lectured on the cohesiveness of discourse in general and the translation of cohesive devices in particular. However, the in-class discussions grounded on the students' translations revealed certain problematic areas in the translation of elliptical cohesive devices having a stylistic, rhetorical and sociolectal function. The observations legitimated the hypothesis that some cohesive devices pose problems in student translation when they carry additional implicit information. Hence, a systematic study into the nature of the deficient aspects was thought necessary with a view to formulating teaching measures that would enable the students to find suitable solutions for the translation of the cohesive devices of ellipsis, substitution and reference in the diverse facets they display. This study also envisages an additional insight into functional aspects of formal links and their translation, as well as into contrastive matters between English and Romanian.

\section{Literature Review}

\subsection{The Translation of Cohesive Devices}

To Newmark "the topic of cohesion [...] has always appeared [...] the most useful constituent of discourse analysis or text linguistics applicable to translation" (1987: 295). One of the major concerns of translators is to produce cohesive target language versions of source language texts. Still, the attention granted to cohesive devices in translation generally seems to be marginal, being overshadowed by other, seemingly more relevant language aspects. But most of the time, cohesion is inherently related to the fluency and naturalness of expression in the language of (re)production. Therefore, considering the implications of cohesion in the language pair involved in translating is a necessary concern of translators. This means that the translator's contrastive knowledge should comprise considerations on the mechanisms of cohesion. Baker acknowledges in this respect that

[t]he translator need only be aware that there are different devices in different languages for creating texture and that the text hangs together by virtue of the semantic and structural relationships that hold between its elements. (Baker 1992: 188)

Other scholars have also discussed the fact that languages possess distinct sets of cohesive devices and means for the creation of cohesive harmony (Hasan 1984) and bonding patterns (Hoey 1991). The unavoidable shifts in cohesion have been addressed by Blum-Kulka, who argues that "the process of translation necessarily entails shifts both in textual and discoursal relationships" (1986: 18). Similarly, Schäffner (2002) refers to the inevitable occurrence of shifts in the translation of cohesive devices, and Larson argues that, if translated one-for-one, cohesive devices would almost certainly distort the intended meaning of the source text. Hence, cohesive devices have to be recognized for what they are and dealt with accordingly in translation (Larson 1984). Trosborg also considers that equivalence in cohesiveness "may not be possible because of diverging linguistic systems in source language and 
target language" and that "equivalence may not even be a desirable criterion" (Trosborg 2002: 42). Referring to narrative texts, van Leuven-Zwart (1990) asserts that the modifications of formal links in translation might affect the narrative function of the text.

Given the scholarly consensus regarding the differences in the manifestation of cohesive devices in different languages and the impossibility of transferring them as such from one language to another, a theory with regard to their translation can be formulated only in very general terms. The multitude of the variables employed in translating formal links depends on factors like: the structural organization of the language pairs involved in translation, the genre, specific textual features, their additional communicative functions, etc.

Studies have been undertaken into the contrastive issues of cohesive devices with regard to certain language pairs. For instance, an examination of shifts in cohesion and bonding patterns in translations from English into Korean was undertaken with a view to investigating the reasons behind these shifts. These have been identified as being structural differences and translation-inherent processes (Kirk 2005). Another study uses Halliday and Hasan's (1976) theory to explore lexical cohesion and its translation equivalence, which is examined in terms of lexical strategies (LotfipourSaedi 1997). Drawing also on Halliday and Hasan's (1976) cohesive theory, Wu (2014) embarks upon a study of shifts of cohesive devices in translating English texts into Chinese. The shifts in cohesion are investigated in relation to two language differences, namely topic-prominence and subject-prominence; parataxis and hypotaxis. The conclusions highlight the fact that Chinese discourse coherence is not always achieved by means of explicit cohesive devices, but by way of implicit cohesive mechanisms. In a study dedicated to the investigation of the language of interpreting, but extendable to that of translation, Shlesinger (1995) observed that there are shifts in cohesion materialized in the replacement of substitution and ellipsis with the repetition of lexical items or synonyms thereof. This observation rests on the analysis of discourse interpreted from English into Hebrew and the other way round. Shlesinger further mentions that this finding can be used as an explicitation hypothesis and can be extended to written translations and that, "regardless of the languages concerned, the interpreter tends to render implicit forms more explicitly" (Shlesinger 1995: 210).

Not much research has been carried out on the topic of cohesive devices from a contrastive perspective employing the language pair English and Romanian. An example though is the exploration of the Romanian Translational Corpus (RoTC), a newspaper corpus, which was used to examine ellipsis in translated and non-translated texts and thereby test the explicitation hypothesis with reference to the impact of the anaphoric zero article on the translational language. The occurrence of explicitation was confirmed, which is without doubt a useful finding in the area of translation. However, the study was undertaken by researchers in computational linguistics and its main purpose was to test the validity of some electronic tools (Ilisei, Mihăilă et al. 2011).

The translatability of ellipsis and substitution from English into Romanian was tackled in a small-scale study, which confirmed that the translation of ellipsis and substitution cannot follow precise rules, but each situation needs individual assessment and translation strategies applied accordingly. For instance, the pronouns one 
and ones, which are prevalent substitutes in English, cannot always be translated by their primary Romanian equivalents unul and unii, but repetition is preferred. The same solution is usually adequate for the translation of English auxiliary verbs into Romanian, which are heavily used as substitutes (Arhire 2003). A brief account of the translation of situational ellipsis in James Ellroy's White Jazz, as a marginal device among others is offered by two Romanian researchers, the translators themselves. The findings highlight the fact that an equivalent to ellipsis could not always be found in the target language due to structural differences in the two languages. Compensatory means had to be found in order to avoid losses, the translators usually opting for paraphrase (Protopopescu and Vișan 2008).

Since such similar findings have been obtained from research into the translation of cohesive devices irrespective of the language pairs involved, it seems that partial equivalence is the most that can be achieved in translation at formal level. Cohesion is a discourse feature, the mechanisms of which are unique in each language. Given this, the functional and communicational value of formal links which might be of additional relevance in translation should be further investigated.

\subsection{Ellipsis, Substitution and Reference}

Ellipsis, substitution and reference are among the devices that establish formal textual connectedness and generate cohesion. Their commonalities can be defined in terms of their feature of coreferentiality since none of them acquires meaning on its own or is independent from the context. The definitions given to these cohesive devices lack consistency and the distinction among them has been nuanced differently in the literature both as regards the general consideration at the international level (Halliday and Hasan 1976; Hoey 1991; Baker 1992; Toolan 1998; Wilson 2000; Merchant 2001; McShane 2005; Johnson 2008) and the particular reference to cohesion in Romanian (Bidu-Vrănceanu, Călărașu et al. 2001, Stoichițoiu-Ichim 2002).

Perhaps a unitary theory valid for all the languages cannot exist considering that different languages use cohesive devices in different ways and that factors outside the grammatical systems of languages come into play. An elliptical discourse in a language is likely to differ in the degree of compression, manifestation and effect when transferred to another language as such. Also, the languages in contact in translation play an important part in the translator's decision-making process. As Blum-Kulka (1986: 21) asserts, "[t]he choice involved in the types of cohesive markers used in a particular text can affect the texture (as being loose or dense) as well as the style and meaning of that text."

If the elliptical language is a marker of the author's idiosyncrasy or of a character's idiolect or sociolect, its functional content needs to be evaluated and, if possible, preserved in the target language. Also, the lexical omissions or syntactic gaps in fictional work are often compensated by enhanced cohesion or stylistic effect or both. In other words, lexical scarcity and deviations from explicit and full syntactic patterns might favour expressiveness, thus enriching the discourse and lifting it above the neutral level (Arhire 2011). The grammatical occurrence of ellipsis, substitution and reference falls within the area of linguistic norms, whereas their stylistic counterparts are excluded from this framework. However, these two functions which such devices can simultaneously display cannot be clearly separated, which makes their 
translation even more challenging. Such instances of language have been under scrutiny in this study and the investigation of their translation from English into Romanian is partly presented in the analysis section.

\subsubsection{Ellipsis}

Looking at some linguists' views on the problem of ellipsis and syntactic omission (Toolan 1998; Wilson 2000; Merchant 2001; McShane 2005; Johnson 2008), their common consideration can be roughly reduced to ellipsis being the omission of a second mention of language items which are implicit and retrievable from the context. The meaning is obvious without taking any material syntactic form. Merchant considers that "[n]owhere does this sound - meaning correspondence break down more spectacularly than in the case of ellipsis" (2001: 1). It seems that language users possess intuitions about the need to avoid excessive repetition and about what sounds overly elliptical (McShane 2005). Ellipsis generates a cohesive textual relation which invites the speaker to interpret and recover some unexpressed meaning.

\subsubsection{Substitution}

Substitution and ellipsis are related cohesive devices, their common point being the omission from discourse of lexical units. As Halliday puts it, they are "variants of the same type of cohesive relation" (1985/1994: 317). Toolan (1998) labels them partial ellipsis and full ellipsis. As regards full ellipsis (referred to as ellipsis in this paper), which entails the full omission of a stretch of language, partial ellipsis (termed substitution in this paper) is a condensed or abridged structure standing for an entire sentence or the replacement of a word by another. The most common replacement words in English are do, one and the same (Baker 1992). Like ellipsis, substitution is considered to indicate grammatical relations with no semantic load (Halliday and Hasan 1976).

\subsubsection{Reference}

In contrast to ellipsis and substitution, referring expressions create semantic relations rather than grammatical ones. They are endophoric - whether anaphoric or cataphoric - and have the quality of offering an alternative to a concept or an idea in order to avoid redundancy and foster cohesion. Referring expressions are lexical units that direct the reader to another spot in the discourse for interpretation. They are also bound to be interpreted in the contextual environment of their referent. At textual level, this results in cohesion. In Halliday and Hasan's (1976) view, reference creates a relationship of identity between two linguistic expressions. The referential meaning can be retrieved by virtue of the identity between a particular thing or class of things and their reference, which announces the entrance of the same thing the second time in the discourse. Coreferentiality is most often realized by means of personal pronouns, deictics, and comparatives (Caldas-Coulthard 2000). English often employs other items for reference though, such as demonstratives or other lexical units arranged in referring strings of words. Romanian also, which inflects verbs for person, number and gender, seems to tend towards the pronominal and demonstrative reference system (Bidu-Vrănceanu, Călărașu et al. 2001: 45-47, 113, $158,412,425)$. Pronouns are the most common referring expressions in Romanian 
just as in English. However, there can be different patterns of reference between languages, as Baker (1992) claims.

The system of reference can vary considerably in different text types, genres or registers (Fox 1986). This is also revealed in the translational corpus under assessment, where the narrative and the dialogue employ different manifestations of elliptical ways of expression as cohesive and/or stylistic devices. For instance, unlike English, Romanian, which inflects verbs for person, number and gender, seems to tend towards lexical repetition.

\section{Research Methodology}

\subsection{The Learners and the Corpus}

The analysis carried out in this study is based on a corpus of forty-three graduate student translations, which were collected during three academic years. All the students attending the MA programme are Romanian native speakers, graduates of a Faculty of Letters in Romania and are English majors or minors. They were also lectured in Translation Studies and attended practical in-class translation sessions beforehand. This means that their background knowledge, as well as their command of English and Romanian is similar, the students making up fairly homogenous groups.

The corpus subject to investigation is a translational learner corpus, comprising the MA students' translations from English into Romanian, which were assessed against the source language text in English, the short story Black Angels by the American writer B. J. Friedman (1983). ${ }^{1}$ The size (almost 102,000 words) of the corpus is of little bearing since only specific language issues were selected from the source language text and evaluated in all the translations. What is important here is the number of translations, the analysis of which is sufficient to draw reliable conclusions. As Bowker and Pearson (2002) claim, there are no fixed rules to determine the ideal size of a corpus as long as it meets the needs of the project. The translations were home assignments and were sent to the trainer before they were discussed in class. Translations exceeding the deadline established ahead of the in-class sessions were not included in the corpus since the discussions would have influenced the translations. Only the students' individual work was to be evaluated, considering that the students were about to become autonomous translators. The trainees were also informed of the project to be carried out based on their translations with a view to fostering their responsibility regarding the reliability of the research depending on the quality of their translations.

\subsection{The Source Language Text}

In the short story Black Angels by Friedman (1983), the dialogue takes place between two characters belonging to different social classes. Stefano is a freelance writer of technical manuals, whereas Cotten is an African-American worker employed by Stefano for some maintenance work to his garden and house. Cotten's speech is characterized by colloquialism, slang and ungrammatical English throughout the dialogue, all of which are markers of his sociolect. Even if Stefano himself becomes 
casual in speech at times, he never uses ungrammatical language. Even though elliptical cohesive devices are naturally present in Stefano's speech, the elliptical way of speaking is a feature of Cotten's careless speech and appears more prominent than in his interlocutor's. The distinct features of the two heroes arise chiefly through the obvious difference in their way of speaking. The social context represents the core problem raised by the author, requiring the translators' conscious engagement.

The following examples of the two heroes' elliptical speech illustrate the sociolectal difference between them. Stefano's utterances exhibit cohesive devices typical for informal face-to-face interaction:

1) Which address did you go to? [...] $\Delta$ Big old place on the corner of Spring and Rooter. $^{2}$

(Friedman 1983: 304)

2) They're doing a great job on $<$ mine $>$.

(Friedman 1983: 305)

In contrast, Cotten's elliptical speech is not only highly informal, but also repeatedly ungrammatical:

3) She'll shape up $\Delta$ time we get the fourth coat on.

(Friedman 1983: 306)

4) $\Delta$ Take about two and a half days.

(Friedman 1983: 305)

5) It $<$ do $>$.

(Friedman 1983: 309)

\subsection{Research methods}

The empirical study reports on the assessment of the Romanian translation trainees' ability to deal with the translation of ellipsis, substitution and reference. The evaluation follows a two-fold coordinate: the translation of cohesive devices as such, and the preservation of the additional stylistic, rhetorical or sociolectal functions embedded in these devices. The examples subject to analysis are depicted from the dialogue of the two characters presented above. They naturally interact by customizing their responses so as to incorporate the other's utterances without unnecessary repetition. The additional values encompassed in some elliptical replies are analyzed in contrast to others which are void of any stylistic, rhetorical or sociolectal content.

The data for analysis has been extracted manually from the corpus. The manual data extraction posed no problems due to the reduced size of the corpus, but the main reason for this method is that a preliminary qualitative evaluation of the examples was necessary. This evaluation enabled a careful selection of the cohesive devices to be analyzed based on the criterion of relevance, but was also essential in order to distinguish between purely cohesive devices and stylistically loaded ones.

Reference is made to simplification, explicitation and neutralization described in the literature as universal or recurrent features of translation. They are only used as assessment tools, with no direct intention of reporting on the frequency of their occurrence. Simplification is understood here as the use of fewer words in translation (Blum-Kulka and Levenston 1983) and is related to the presence of ellipsis in the target language text when other cohesive devices are used in the source language. 
Explicitation is the opposite of simplification, namely the use of more words in translation and enhanced clarification of the message or, as Baker defines it: "an overall tendency to spell things out rather than leave them implicit in translation" (Baker 1996: 180). In this paper, it is usually associated with the translation of ellipsis by means of other, more explicit cohesive devices. With a view to obtaining more systematic results from the evaluation of the students' translations, I have resorted to the distinction between the obligatory and non-obligatory occurrence of simplification and explicitation. The starting point for this distinction is Klaudy's classification of the types of explicitation into obligatory, optional, pragmatic and translationinherent (1996). For suitability reasons, I have appealed only to the obligatory one and have extended it to simplification. According to Klaudy (1996), obligatory explicitation intervenes due to the lack of structural equivalence between source language and target language. But if explicitation can be obligatory, simplification can also occur due structural differences and can be obligatory as well. I consider such occurrences as techniques that the students appealed to rather than evidence of recurrent features of translation. In reverse, the unnecessary shifts manifested in explicitation and simplification, when a more suitable structural equivalent could have been provided, are considered non-obligatory. As concerns the phenomenon of neutralization, it entails either a diminished stylistic effect (Bassnett 2002) or the cancellation of some rhetorical properties (Künzli 2004) or the characters' less intense emotions and the reduction of the social distance between them (Zlatnar Moe 2010). All these instances of neutralization actually loop the equivalent effect principle, which Newmark (1988) considers of paramount importance in translation. Given the significance of the stylistic, rhetorical and sociolectal equivalence in the translation of this text, in my view, neutralization cannot fall within the categories of obligatory or non-obligatory features of translated language. It also cannot be viewed as a translation strategy, but only as a deficiency in translation. The equivalent effect is expected to be compensated for by other target language means if formal equivalence is either not possible or does not render the source language effect.

In short, the appropriateness of the students' translations was assessed in terms of their preserving the functional content embedded in the cohesive structure of the source text. Both quantitative and qualitative means of analysis were employed. Thereby a statistic outcome of the shifts in cohesion and /or resulting stylistic value and the reasons why certain translation features/ strategies were employed could subsequently be inferred.

A number of 30 examples of simple cohesive devices and others carrying stylistic, rhetorical and sociolectal content were investigated. The analysis below presents some of the most representative and interesting examples for each device as they appear in each character's speech. The findings deriving from the analysis of these illustrative examples are in line with the overall results of the analysis.

\section{Analysis and Findings}

\subsection{Analysis of Ellipsis}

Cotten's speech is often marked by elliptical utterances from which auxiliary verbs are omitted. This has a twofold bearing upon the translation: firstly such ellipses 
provide Cotten with the distinguishing feature of a careless language user with a low educational background, which contrasts heavily with his interlocutor's speech; secondly, the translation of such elliptical structures poses problems to Romanian translators due to lack of structural equivalence.

6) $\Delta$ You think you $\Delta$ any good?

(Friedman 1983: 308)

The ellipses here are primarily sociolectal markers with their translatability concerning the rhetorical function rather than the cohesion. The full and formally correct version, Do you think you are any good? would have been neutral and void of the sociolectal marker. However, the person, number, gender and tense are inflected in the Romanian verbs and no auxiliary verbs are used to express interrogations. The information about the subject is also defined by the verb inflection, so pronouns are only optionally expressed explicitly. The Romanian for Do you think? is Crezi?. Similarly, you are is esti in Romanian. Given the structural differences and the fact that the ellipses in the English original bear sociolectal connotations, the translation requires some effort. The analysis of the students' translations of this utterance revealed that most of them display clear instances of neutralization, being fully correct, clear and cohesive. Thus, the phenomenon of explicitation is also employed to the same extent as neutralization. Several similar structural ways of expression were opted for, among which the most frequent is:

a) Crezi că ești bun de ceva? ${ }^{3}$

[Do you think you are any good?] $]^{4}$

Only two translations used the ellipsis of the Romanian verb esti (you are), creating inappropriate and unnatural Romanian language though. The rhetorical value of the utterance is thereby affected without providing an equivalent colloquial solution. It is rather the language of a foreigner than that of a careless native speaker. Hence, these translations produce an important shift in the character's image as a social being and alter the identity that the author endowed him with. The two translations referred to above are:

b) Tu crezi că tu $\Delta$ bun de ceva?

c) Crezi că tu $\Delta$ bun de ceva?

These translations confirm the previously stated assertion that cohesive mechanisms do not necessarily coincide in different languages. The students performed a mechanical transfer and thus the ellipses sound artificial in Romanian.

Another translation version attempted to render Cotten's careless speech by omitting the definite article $(-1)$ that should be attached to a noun and marking the omission by an apostrophe (capu' instead of capul). The noun is part of an idiomatic expression which carries the same semantic content. The intention is worth praising since it is a measure to compensate for the structural difference by proposing an authentic careless and informal use of Romanian:

d) Crezi că-i ceva de capu’ tău?

To sum up, the great majority of the translations comprised in the learner corpus exhibit explicitation as an obligatory solution due to structural differences between 
source language and target language. Moreover, explicitation triggers the neutralization of Cotten's social status. 93\% of the students did not translate the English ellipsis as such for a good reason, but found no compensatory solution for the character's speech peculiarity. Their translations either produce a shift in the character's identity, or are devoid of authenticity and credibility. Out of the three remaining translations, the two preserving the ellipses are inappropriate, whereas the third compensates for the Romanian structural lack of equivalence by opting for an incomplete lexical item indicating the character's speech carelessness.

The same register marker is carried by a double ellipsis in another question that Cotten addresses Stefano:

7) How long $\Delta$ she $\Delta$ gone?

(Friedman 1983: 308)

Both auxiliary verbs have been omitted, which is consistent with the way Cotten's social status is exhibited throughout the dialogue. Most of the students' translations neutralize Cotten's sociolect again by using the explicit and correct manner of expression:

a) De cât timp e plecată? (or similar)

A number of translations (16\%) exhibit attempts at rendering the character's careless speech, which indicates the students' awareness of the importance of revealing Cotten's social status as deriving from his manner of speaking. Out of them, seven students translated in an equivalent elliptical way, omitting the verb este (is), which is unnatural even in colloquial or ungrammatical Romanian. The translations characterize Cotten again as a foreigner rather than a less educated person.

b) De când $\Delta$ plecată? (or similar)

Three other students recognized both the ellipses as rhetorical devices and the inadequacy of ellipsis in Romanian. They used a rather dialectal Romanian version, actually shifting from a social dialect to a regional one. Notwithstanding their positive intentions to find a compensatory element that would not neutralize the register level, the effect is a different one, situating Cotten in a particular geographical region rather than in a particular social class:

c) De când îi plecată?

A more successful attempt at displaying the hero's careless speech is made by one student only who uses an incomplete word. The missing final letter in the adverbial is replaced by an apostrophe:

d) De cân' a plecat?

Quantitatively speaking, this example indicates that $74.4 \%$ of the translations are characterized by neutralization and explicitation simultaneously, thus erasing the hero's speech markers. As in the above example, the translated versions which preserved the ellipses generated unnatural Romanian language (16\%), being typical of a foreigner rather than of a less educated native speaker. Out of the four students attempting to compensate for the structural difference between English and Romanian, three opted for dialectal, thus inappropriate versions, and one student rendered Cotten's careless speech by using an incomplete word. 
From the two examples of ellipsis discussed above, the finding emerges that, apart from being a cohesive device, ellipsis can be stylistically loaded to mark a sociolect. Since it cannot always be structurally and functionally equivalent in English and Romanian, the translation process becomes quite demanding. The Romanian versions avoiding neutrality are worth praising in intention, but are deficient in terms of the light in which they present the hero. Thus, the solution is to find a compensatory device that can be of lexical or structural nature so as to avoid a loss that is more far-reaching, operating beyond the character level. It changes the entire social context of the story, the core theme of which is racial discrimination. Thus, it is ultimately the interpretation of the discourse as a whole that is affected, the loss working at the macro-contextual level.

In his turn, Stefano uses elliptical sentences at times. Nonetheless, the function of ellipsis is of a different nature, in that it establishes cohesive relations among utterances. In the following two examples, ellipsis is used in instances of natural and spontaneous speech:

8) What would you charge me? $\Delta$ An hour?

(Friedman 1983: 309)

The elliptical sentence An hour? is an addition to the initial question What would you charge me? Stefano's pause, marking his hesitation, has a definite stylistic load denoting his emotional state caused by his financial discomfort. The double function of this ellipsis - as a formal link and as a stylistic device - can be perfectly preserved in Romanian if translated by ellipsis. However, ellipsis was the solution offered only by seven students (16.2\%):

a) Cât mi-ai cere? $\Delta$ Pe oră? (or similar)

[What would you charge me? An hour?]

The other thirty-six trainees (83.7\%) offered a more explicit and neutral target language version by joining the two questions. Undoubtedly, this is the way a perfectly fluent and neutral idea would be constructed in writing. However, in this very context, the emotional content and the spontaneous speech would be best rendered by means of ellipsis in Romanian, too. The example of the merged questions is presented below:

b) Cât mi-ai cere pe oră? (or similar)

[What would you charge me for an hour?]

The loss lies in the stylistic content even if the neutral expression fosters readability. Thus, despite ellipsis being used in Stefano's speech for a different purpose than in Cotten's, the features of explicitation and neutralization are present in the learner corpus to a considerable extent. Moreover, as in all the examples analyzed so far, it seems that neutralization occurs as a result of applying explicitation.

Another example of Stefano's elliptical speech enforces the belief that the author is employing ellipsis as a stylistic device:

9) Anyway, I'll be goddamned if I know what to do. $\Delta$ Wait around? $\Delta$ Pretend she's never coming back?

(Friedman 1983: 308) 
Again, Stefano utters out his thoughts as they occur to him, in segments separated by natural, hesitant pauses. Having been left by his wife, his rather desperate state of mind can be inferred from his elliptical rhetorical questions. The full sentences Shall I wait around? and Shall I pretend she's never coming back? would have reduced the emotional charge. However, the obligatory Romanian structure does not permit the use of ellipsis:

a) Să aștept? Să mă prefac că nu se mai întoarce?

[Shall I wait? Shall I pretend she's not coming back?]

This translation or similar ones have been offered by all the trainees. The stylistic effect is considerably reduced even if part of it is preserved by the use of rhetorical questions.

The examples (8) and (9) above exhibit the ellipsis as a rhetorical device. In the former it could have been preserved in translation, whereas the latter does not offer any option for the transfer of ellipsis to Romanian due to structural constraints.

\subsection{Analysis of Substitution}

In the following example, coreferentiality is achieved first by substitution and then by means of ellipsis, the two cohesive devices having a common referent:

10) I've had nice analysts, tough <ones $>, \Delta$ all kinds.

(Friedman 1983: 309)

In Stefano's turn above, the word analysts is first substituted by the pronoun ones and then completely omitted. The obvious function of these devices is to avoid repetition when the proximity of the referent enables the recovery of the meaning. The translation of the ellipsis into Romanian is both possible and desirable. Pronominal substitution is also possible in Romanian, but the English pronouns one and ones do not have direct equivalents. Instead, the Romanian pronouns used as cohesive substitutes are much more various and context dependent. Here, the equivalent of the English ones is unii (some), which is often associated with altii (some others). However, most of the time, ellipsis is the preferred cohesive device in the students' translations. With all the lexical variations, ellipsis was used twice, for both substitution and ellipsis occurring in the English source text. The structural pattern in thirty $(69.7 \%)$ of the translations is:

a) Am avut analiști blânzi, $\Delta$ duri, $\Delta$ de toate felurile. (or similar)

Thirteen trainees (30.2\%) used a substitute for ones in unii (some) or alții (some others), thus offering a structurally equivalent version in Romanian:

b) Am avut analiști blânzi, <unii > duri, $\Delta$ de toate felurile.

c) Am avut analiști blânzi, <alții > duri, $\Delta$ de toate felurile.

Still, a more detached approach to the source language sentence could have led to a more natural translation into Romanian by using possible substitutes and operating a syntactic modification such as:

d) Am avut analiști de toate felurile: <unii > blânzi, <alții > duri.

[I had all kinds of analysts: some nice, others tough.] 
The students' use of pronominal substitutes in Romanian seems a forced attempt to provide structural equivalence or occurs due to the influence of the source language structure.

The analysis of the substitution translated into Romanian confirms the fact that pronominal substitution is structurally possible in Romanian, too. However, in the example above, the use of pronominal substitutes affects the naturalness of Stefano's spontaneous speech. In this respect, the double elliptical translation option preserves at its best the natural flow of thought reflected in casual face-to-face speech interaction. Drawing on the consideration that simplification means using fewer words in translation (Blum-Kulka and Levenston 1983), simplification can be identified as the most suitable translation strategy.

Below is another example using the substitute one, followed closely by another substitution expressed through the verb do, both being among the most commonly used substitutes in English discourses:

11) Let's just finish up this hour, all right? Then we'll see about other times. This <one $>$ doesn't count, does it?

12) It $<$ do $>$.

(Friedman 1983: 309)

To start with the first referring expression, one (11) refers to the previously stated noun hour, naturally avoiding its repetition. This context, in which one comes after a demonstrative, has no similar solution in Romanian, as it had in the previous example (10). There, ones followed an adjective (tough ones), which allowed a pronominal substitute in Romanian too. Instead, in this example, the translations proved that there is either the option to use ellipsis in Romanian (by expressing only asta - the demonstrative meaning this):

a) $\Delta$ Asta nu contează.

[This does not count.]

or repetition (ora asta, meaning this hour):

b) Ora asta nu contează.

[This hour does not count.]

The great majority of the translated versions (88.3\%) preserved only the demonstrative in Romanian, that is, they used ellipsis and only five students (11.6\%) translated in a more explicit manner, repeating the noun ora (hour) or avoiding the repetition by using the contextually synonymous noun data (data asta, meaning this time). The fact that nobody used substitution, but either simplification (ellipsis) or explicitation (repetition) is explained by the fact that irrespective of the option for one or the other translation, it is an obligatory choice determined by the lack of structural equivalence.

The second substitute in this example (12), the auxiliary $d o$, is used to replace a verb in the present tense simple. The negative statement (This one doesn't count) and the tag interrogative following it (does it?) naturally use the same auxiliary (do) and trigger the turn It do (wrongly used here to mark Cotten's sociolect). The explicit answer for It do would have been It count(s), which would have affected the cohesion of the dialogue. As far as Romanian is concerned, negative and interrogative sentences do not employ auxiliary verbs and tag questions follow completely different 
rules, also not using an auxiliary corresponding to the verb in the clause preceding it. That is why almost half of the translations (48.8\%) trying to preserve the hero's sociolect simply rendered the meaning by:

a) Ba da $\Delta$ or $\mathrm{Ba} \Delta$ [Oh, yes $\Delta]$

The rest of the message is omitted but understood. The occurrence of ellipsis in the target text for a substitution in the source text is a manifestation of simplification and is in line with the prevailing solutions found in the previous example of substitution (11).

The other learners (51.1\%) either repeated the verb used in the question to translate the answer or clarified the message in another way:

b) $\Delta$ Asta nu se pune.

Ba se pune.

[This does not count. It counts.]

c) $\Delta$ Asta nu contează, da?

Sigur că contează.

[This does not count, does it?

Of course it counts.]

d) $\Delta$ Asta nu se ia în considerare, nu-i așa?

Ba da, se ia.

[This is not taken into account, is it?

Yes, it is.]

All these three solutions are explicitations. Hence, simplification and explicitation were almost equally employed in translation as strategies due to the fact that both of them can be obligatory solutions. So the Romanian translations are adequate either way. Moreover, since the grammatical disagreement between the question does $i t$ ? and its answer It do could not be rendered in Romanian, we can simultaneously observe the phenomenon of neutralization in (12). Cotten's social position and the status difference between the two interacting characters are neutralized in the translations, with no student attempting to take any compensatory measures.

As previously stated, pronouns are among the most common substitutes in English. The following example presents such a situation, where a noun is replaced by a pronoun:

13) I would never let a colored guy touch my place.

They're doing a great job on $<$ mine $>$.

(Friedman 1983: 306)

Romanian pronominal substitution is also possible, but only nine students (20.9\%) opted for such a structural equivalent in translation:

a) Nu aș lăsa niciodată un negru să se atingă de proprietatea mea.

Se ocupă de minune de $<$ a mea $>$. (or similar)

[I would never let a negro touch my place.

They're doing a great job on mine.] 
Other nine students (20.9\%) used explicitation by repeating the noun:

b) Nu aș lăsa niciodată un om de culoare să se atingă de grădina mea.

Fac treabă bună în grădina mea. (or similar)

[I would never let a colored guy touch my garden.

They're doing a great job in my garden.]

The rest of the students used other translation options, which do not fall within the scope of this discussion. However, the evaluation of the ones presented above is definitely in favour of the former solution, substitution, while the latter, repetition, proves to affect the cohesive flow of the discourse. Except for the $20.9 \%$ of the target texts exhibiting explicitation, no other translation feature is obvious.

To briefly summarize the analysis of substitution in translation, it is again evident that the situations are diverse and need to be treated distinctly. The pronoun one proved to require different treatment in the two examples above (11 and 12). Yet, ellipsis generally seemed to be the most suitable option, preferred to repetition or substitution (even if it was structurally possible). This leads to the finding that simplification due to lexical reduction is the best choice when transferring such substitution to Romanian. The auxiliary verbs in interrogatives, although extensively used in English as substitutes, do not have counterparts in Romanian. Therefore, other means are used, employing either simplification or explicitation. Or, at times, other substitutes can be used (example 13). The pronoun mine (al meu, a mea) as substitute reaffirmed the Romanian pronominal substitution as a valid translation option, being a suitable equivalent cohesive device. Regarding the specific social context of this short story, a significant loss occurs in the translation of Cotten's ungrammatical answer (It do). Given the structural differences, a Romanian translator would need to be creative in order to render the hero's educational level.

\subsection{Analysis of Reference}

The most common referring expressions are pronouns and demonstratives. Both categories are illustrated in the following example proposed for analysis. In order to enable access to the interpretation of the referent, a larger context is provided from the dialogue on Stefano's proposal to have Cotten act as his confident and consultant:

14) "I just sound off and then you come in with the haymaker, the way you just did. Just for fun, what would you charge me? An hour?"

"Fo' hundred," said the Negro.

"Four hundred. That's really a laugh. You must be out of your head. What are you, crazy? Don't you know I was just kidding around?[...] Let's just finish up this hour, all right?

Then we'll see about other times. This one doesn't count, does it?"

"It do," said the Negro [...]

15) “That's not really fair, you know," said Stefano. "To count this one. Anyway, we'll see.

16) Maybe we'll try it for a while."

(Friedman 1983: 309) 
The demonstrative That in (14) is an anaphoric reference, the recovery of which is easy due to the immediate proximity of the referent (the price stated in the previous utterance). Although the reference by means of a demonstrative is also possible in Romanian, only $51.1 \%$ of the students used a demonstrative (asta) to translate the English one in (14) and $34.8 \%$ in (15):

(14)

a) Asta-i chiar de râs. (or similar)

[This is really a laugh.]

15)

a) Asta nu e tocmai corect. (or similar)

[This is not really correct.]

Ellipsis and reformulation were used in proportion of $48.8 \%$ for (14) and $62.7 \%$ for (15):

14)

b) Ce glumă bună./ Glumești./ Mă faci să râd.

[What a good joke./ You're kidding. / You make me laugh.]

15)

b) Să știi că nu e tocmai corect. (or similar)

[Let me tell you that it's not really fair.]

Repetition and thus explicitation has been observed in only one of the translations to (15), which is $2.3 \%$ :

15)

c) $\mathrm{Nu}$ e corect s-o numeri și pe asta.

[It's not fair to count this one.]

The two examples discussed above (14 and 15) have shown that there is equivalence between demonstratives as referring expressions between English and Romanian. However, the free translation of the English language item comprising a demonstrative is also possible. The demonstratives can be successfully replaced by other Romanian language means as are suitable in each context. Ellipsis is one of the options, and repetition (entailing explicitation) is another.

The spot marked (16) in the extract above signals the presence of the anaphoric referring pronoun $i t$, which also requires semantic recovery. The explicit version could have been Maybe we'll try meeting for a while (or similar). It does not refer to a word or a phrase, but to a situational and semantic context, to an idea. The translations use a demonstrative alone as an equivalent in 6 instances (13.9\%):

16)

a) Poate vom încerca asta pentru un timp. (or similar) [Maybe we'll try this out for some time.]

Three other translation versions (9.3\%) offer solutions in an adverbial reference: așa (this way):

16)

b) Poate vom încerca așa pentru o perioadă. (or similar) [Maybe we'll try (it) out this way for some time.] 
In total, $20.8 \%$ of the students opted for reference in translation. Twenty-six (60.4\%) of the translations omit the reference completely, using the ellipsis, whereby they obtain simplification without affecting the cohesion of the Romanian discourse though:

16)

c) Poate vom încerca $\Delta$ pentru o vreme. (or similar)

[Maybe we'll try for a while.]

Explicitation is observable in four translations (9.3\%) and is achieved by inserting a noun to join a demonstrative even if the noun is a semantically low-density one such as treaba asta/ chestia asta (this issue/ this thing):

16)

d) Poate încercăm treaba asta pentru o vreme. (or similar)

[Maybe we'll try this thing for a while.]

No pronominal reference was used in any of the translations since it is not appropriate in this context even if it is structurally possible. Ellipsis stands out as the most commonly used translation solution (60.4\%), which indeed is the most appropriate and natural option in Romanian. Thus, simplification, even though prevalent, does not affect the target language text and can be considered the suitable translation strategy. The reference materialized in the adverbial așa, meaning this way (in three versions), is also suitable but the demonstrative alone is felt somehow alien and is not necessary, and the four cases of explicitation are the least preferred. Using a lowdensity lexical item is not justified. Thus, if explicitation is a shortcoming of the target language text, simplification can be considered a positive measure to be taken in such circumstances. The fact that a pronominal reference word (for the English pronoun) has not been used is another proof that the cohesive language tools are not to be approached in translation as one-to-one equivalents, but evaluated in the particular situations they occur, while adapting the translation measures accordingly. In other contexts pronouns are successfully used as referring expressions in Romanian as well.

Reference can also be achieved by way of larger lexical strings rather than single words. Below is an example of a complex reference whose recoverability entails a look at the broader context:

17) Finally, when Stefano sank back to catch his breath, the gardener asked a question: "You think you any good?"

"What do you mean," said Stefano. "Of course I do. Oh, I get what you're driving at. If I thought I was worth anything, I wouldn't let all of this kill me. I'd just kind of brace myself, dig out and really build something fine for myself. Funny how you make just the right remark. It's really amazing. You know I've done the analysis bit. Never meant a damn thing to me. I've always had analysts, tough one, all kinds. But the way you just let me sound off and then asked that one thing."

(Friedman 1983: 308-309)

In contrast to the reference words analyzed above, which were simple cohesive devices, in this example reference is enriched with stylistic load. The underlined referring expression could have been neutrally expressed by that alone (... then asked that). The emphasis embedded in the extended reference ... then asked that one thing expresses Stefano's acknowledgement that Cotten hit his core problem by asking You 
think you any good?. The correct meaning and the stylistic effect were identified and treated as such by $34.2 \%$ of the students, who provided different solutions as follows: $18.4 \%$ used explicitation by lexical addition and/ or syntactic means. This way they compensated for the impossibility of translating the pronoun one, but provided a more explicit emphasis, clarifying the meaning:

17) (see above)

a) apoi ai pus exact întrebarea potrivită (or similar) [then you asked exactly the right question]

(My back translation)

It is interesting that $15.7 \%$ of the trainees chose to add three dots to preserve the emphasis, thus compensating for the stylistic scarcity that words often display as compared to non-verbal language means. The fact that punctuation marks can take the stead of words while enriching the message emotionally is no novelty; linguistic silence is one of the prolific devices of the literary language. Despite the fact that punctuation is generally known to enhance readability, entailing simplification or normalization (Olohan 2004), here, the three dots represent a non-verbal presence meant to mark an omission and generate a less common feature of translation, called implicitation (Pym 2010). Here is a sample of what the students have suggested:

17) (see above)

b) apoi ai întrebat acel lucru ... (or similar)

[then you asked that thing...]

$65.7 \%$ of the students omitted the emphasis, obtaining translations that are not only explicit but also devoid of any emotional or stylistic load, neutralizing the intended effect generated by Stefano's surprise at Cotten's ability as an 'analyst.' Thus, explicitation and neutralization co-occur, neutralization being generated by explicitation.

\section{Conclusions and Translation Teaching Methodology}

The main objective pursued in this study was to test the hypothesis that the translation of cohesive devices poses problems in student translation when they are loaded with stylistic, sociolectal or rhetorical value. The analysis presented in this paper was based on a number of examples, some of which were selected considering the stylistic diversity embedded in the cohesive devices. Others were meant to illustrate the translation of ellipsis, substitution and reference as cohesive links only.

The methodology for analyzing the translational learner corpus included the occurrence of simplification, explicitation and neutralization. The quantitative data comprising the students' translations of ellipsis indicate that explicitation and neutralization co-occur in $87.5 \%$ of the translations. In most cases, explicitation is compulsory due to structural differences and triggers the neutralization of the stylistic or sociolectal effect.

Substitution and reference exhibit some commonalities in that their stylistic and sociolectal value is reduced both in terms of frequency and expressiveness as compared to ellipsis. The translations exhibit the co-occurrence of explicitation and neutralization (15.5\% with substitution and $7.65 \%$ with reference) only in the cases when substitution and reference bear stylistic content. When they operate only as cohesive devices, simplification prevails in the translation of both devices $(68 \%$ with 
substitution and 55\% with reference). Both simplification and explicitation proved to be valid translation options of the same source language devices even though the former entails a reduction usually materialized in ellipsis, whereas the latter is realized by means of repetition. Neither affects the cohesion of the target language text.

When ellipsis, substitution and reference have only the function of formal links, explicitation and simplification usually appear as suitable translation strategies. It can be thus inferred that the translation of cohesive devices is generally not problematic and does not require any effort when the students translate them into their native language. However, the occurrence of neutralization, which is of relevance only in the translation of stylistically charged cohesive devices, indicates the need to pay more attention to the transfer of the stylistic effect. The fact that neutralization was present in high proportions in the trainees' translations confirms the hypothesis that most of them oversaw the stylistic, sociolectal or rhetorical content, which produced serious shifts especially in the social context between the source language text and target language text. Also, contrastiveness in relation to cohesive devices with a stylistic function is irrelevant, since it is only the stylistic effect that ultimately matters irrespective of the correspondence at formal level. Nevertheless, the study confirms the scholarly assertions according to which the cohesive system does not follow unique rules across languages and therefore cannot be transferred as such. Cohesive equivalence does not represent equivalence of cohesive devices, but rather equivalence of the cohesive level of a discourse irrespective of the cohesive means adopted in the target language.

The analysis has also revealed two distinct facets of simplification and explicitation: as translation strategies resorted to in order to produce adequate translations, and as results of inadequate translations entailing losses in the target text.

The conclusions based on the analysis further lead to the formulation of some translator training strategies regarding the translation of cohesive devices. The theoretical framework supporting the translator training activity chiefly serves awareness-raising purposes. With cohesive devices, theory is preferably designed to highlight generalities, with the diverse peculiarities to be left mostly for the practical component of the training and adjusted to the specificities of the languages in contact. Relying on previous experience and on the findings of this study, I suggest the following approach to the teaching of how to translate cohesive devices.

The first step would be raising the trainees' awareness of the importance of cohesion and discourse texture in translation. Asymmetries in the cohesive mechanisms of the languages in contact have to be pinpointed in order to have learners come to terms with structural and formal constraints of the target language and obtain equivalence at the cohesive level. The theory will be better illustrated if relevant examples are inserted.

Secondly, the fact that the cohesive devices can be associated with additional functions should be specified, such as stylistic, rhetorical, idiolectal, sociolectal, pragmatic ones. A balance between the cohesiveness of the devices and their additional functions is to be considered, with the latter of primary importance. The cohesive mechanism is to be freely adapted so as to preserve as much of the pragmatic/stylistic function of the discourse as possible. Trainees should also be instructed that the preservation of the same cohesive devices in the target language might hinder the reproduction of the intended effect. Simplification and explicitation 
are to be considered valid translation methods of ellipsis, substitution and reference as cohesive devices with no additional values. However, these translation methods are not necessarily adequate when the cohesive devices bear stylistic, rhetorical or sociolectal functions.

Thirdly, the inequivalence due to structural differences in cohesive devices should be compensated when the devices are used to provide some communicative value apart from the formal one. This might presuppose a major change at formal level based on creativity.

Fourthly, if idiolectal, sociolectal or rhetorical devices are entailed, the same translation measures should be applied throughout the text as consistency is essential with idiosyncrasies of any kind.

As concerns the limitations of this study, it might be added that the conclusions, as well as the translator training methodology could be enriched or nuanced by further investigations into the diversity of cohesive devices in terms of the functional values they can employ. The examination of more sizable corpora of translations made by professional translators, of other text genres and involving other language pairs would be beneficial to test the validity of the above findings and complete them with new insights into the problem of translating cohesive links and the pedagogy related to it.

\section{NOTES}

1. Friedman, Bruce Jay (1983): Black Angels. In: L. Rust Hills, ed. Great Esquire Fiction. The Finest Stories from the First Fifty Years. Preface by Phillip Moffitt. Introduction by L. Rust Hills. New York: Penguin, 304-309.

2. Ellipsis, substitution and reference are marked in the examples as follows: $\Delta$ ellipsis, <substitution>, reference.

3. The letters a, b, c, d are used to mark the examples of students' translations.

4. Back translations are provided when necessary.

\section{REFERENCES}

Arhire, Mona (2003): The Translation of Ellipsis. In: Marinela Burada, ed. Conference on British and American Studies (Conference on British and American Studies, Brașov, March 2003). Braşov: Transilvania University Publishing House, 45-52.

Arhire, Mona (2011): Valențele expresive ale concentrării limbajului. Brașov: Transilvania University Publishing House.

BAKer, Mona (1992): In Other Words. A Coursebook on Translation, London and New York: Routledge.

Baker, Mona (1996): Corpus-based Translation Studies. The Challenges that Lie Ahead. In: Harold Somers, ed. Terminology, LSP and Translation. Amsterdam: John Benjamins, 175186.

Bassnett, Susan (2002): Translation Studies. Reviewed Edition. London and New York: Routledge.

Bidu-Vrănceanu, Angela, Călărașu, Cristina, Ionescu-Ruxăndoiv, Liliana, et al. (2001): Dicționar de științe ale limbii. București: Nemira.

Blum-Kulka, Shoshona and Levenston, Eddie (1983): Universals of Lexical Simplification. In: Claus FAERCH and Gabriele KASPER, eds. Strategies in Inter-language Communication. London and New York: Longman, 119-139.

Blum-Kulka, Shoshona (1986): Shifts of cohesion and coherence in translation. In: Juliane House and Shoshona Blum-KulKa, eds. Interlingual and. Intercultural Communication. Tübingen: Narr, 17-35. 
Bowker, Lynne and Pearson, Jennifer (2002): Working with Specialized Language: a Practical Guide to Using Corpora. London and New York: Routledge.

Caldas-Coulthard, Carmen Rosa (2000): Written Discourse. Birmingham: The University of Birmingham.

Fox, Barbara. A. (1986): Local patterns and general principles in cognitive processes: anaphora in written and conversational English. Text 6(1):25-51.

Halliday, Michael A.K. (1985/1994): An Introduction to Functional Grammar. $2^{\text {nd }}$ edition. London and Melbourne: Edward Arnold.

Halliday, Michael A. K. and Hasan, Ruqaiya (1976): Cohesion in English. London and New York: Longman

HaSAn, Ruqaiya (1984): Coherence and cohesive harmony. In: James Flood, ed. Understanding Reading Comprehension. Delaware: International Reading Association, 181-219.

Hoey, Michael (1991): Patterns of Lexis in Text. Oxford: Oxford University Press.

Ilisei, Iustina, Mihaila, Claudiu., InkPen, Diana, et al. (2011): The impact of zero pronominal anaphora on translational language: a study on Romanian newspapers. Studia universitaria Babes-Bolyai, informatica. LVI(2):43-50.

Johnson, Kyle (2008): A view of QR from Ellipsis. In: Kyle Johnson, ed. Topics in Ellipsis. Cambridge: Cambridge University Press, 69-94.

KIRK, Sung Hee (2005): Cohesion Shifts in English-Korean Translation. Doctoral Dissertation, Manchester: University of Manchester.

KLAUDY, Kinga (1996): Concretization and generalization of meaning in translation. In: Marcel Thelen and Barbara Lewandoska-Tomaszczyk, eds. Translation and Meaning Part 3, Maastricht: Hogeschool Maastricht, 141-163.

KüNZLI, Alexander (2004): I find that a bit exaggerated - Neutralization in Translation. In: Anastasia Papaconstantinou, ed. Choice and Difference in Translation: The Specifics of Transfer. Athens: The National and Kapodistrian University of Athens, 81-96.

Larson, Mildred L. (1984): Meaning-based Translation: A Guide to Cross-Language Equivalence. Lanhan, New York and Oxford: University Press of America.

Leuven-Zwart, Kitty M. van (1990): Translation and Original: Similarities and Dissimilarities, II. Target. (1):69-95.

Lotfipour-Saedi, Kazem (1997): Lexical Cohesion and Translation Equivalence. Meta 42(1):185-192.

Mcshane, Marjorie. J. (2005): A Theory of Ellipsis, New York: Oxford University Press.

Merchant, Jason (2001): The Syntax of Silence: Sluicing, Islands, and the Theory of Ellipsis. New York: Oxford University Press.

Newmark, Peter (1987): The use of systemic linguistics in translation analysis and criticism. In: Ross Steele and Terry Threadgold, eds. Language Topics: Essays in Honour of Michael Halliday. Amsterdam and Philadelphia: John Benjamins, 293-304.

Newmark, Peter (1988): Approaches to Translation. New Jersey: Prentice Hall.

Olohan, Maeve (2004): Introducing Corpora in Translation Studies. London and New York: Routledge.

Protopopescu, Daria and VIȘAn, Nadina (2008): Compensation and Translation in James Ellroy's White Jazz. Bucharest Working Papers in Linguistics, 10(2):41-50.

Pум, Anthony (2010): Exploring Translation Theories, London and New York: Routledge.

SCHÄFFNER, Christina (2002): Discourse analysis for translation and translator training: status, needs, methods. In: Christina SCHÄFfNER, ed. The Role of Discourse Analysis for Translation and Translator Training, 1-8.

Shlesinger, Miriam (1995): Shifts in cohesion in simultaneous interpreting. The Translator. 1(2):193-214.

Stогснітіоі-Iснім, Adriana (2002): Semiotica discursului juridic. Bucharest: Bucharest University Publishing House.

Toolan, Michael (1998): Language in Literature: An Introduction to Stylistics. London: Hodder Arnold. 
Trosborg, Anna (2002): Discourse analysis as part of translator training. In: Christina SCHäFFNER, ed. The Role of Discourse Analysis for Translation and Translator Training. Contemporary Issues in Language and Society, Vol. 3. Clevedon: Multilingual Matters, 9-52.

Wilson, Peter (2000): Mind The Gap: Ellipsis and Stylistic Variation in Spoken and Written English, London: Longman.

Wu, Jing (2014): Shifts of Cohesive Devices in English-Chinese Translation. Theory and Practice in Language Studies. 4(8):1659-1664.

Zlatnar Moe, Marija (2010): Styling Popular Fiction: A Comparison of Stylistic Shifts in Slovene Translations of Popular Fiction and Literary Prose. Paper presented at IV Congreso Internacional de la Sociedad Española de Estudios Literarios de Cultura Popular, Mallorca. Visited 02 August 2015, http://www.uibcongres.org/congresos/. 